\title{
Lamellation Fractures in the Paleogene Continental Shale Oil Reservoirs in the Qianjiang Depression, Jianghan Basin, China
}

\author{
Lianbo Zeng $\mathbb{D}^{1,2}$ Zhiguo Shu, ${ }^{3}$ Wenya Lyu, ${ }^{1,2}$ Mingjing Zhang, ${ }^{1}$ Hanyong Bao, ${ }^{3}$ \\ Shaoqun Dong, ${ }^{1,2}$ Shuangquan Chen, ${ }^{1,2}$ and Xiang $X u \mathbb{D}^{1,2}$ \\ ${ }^{1}$ State Key Laboratory of Petroleum Resource and Prospecting in China University of Petroleum, Beijing 102249, China \\ ${ }^{2}$ China University of Petroleum, Beijing 102249, China \\ ${ }^{3}$ Jianghan Oilfield Company, Sinopec, Wuhan, Hubei Province 430071, China
}

Correspondence should be addressed to Lianbo Zeng; lbzeng@sina.com

Received 25 December 2020; Accepted 26 April 2021; Published 6 May 2021

Academic Editor: Yingfang Zhou

Copyright ( 2021 Lianbo Zeng et al. This is an open access article distributed under the Creative Commons Attribution License, which permits unrestricted use, distribution, and reproduction in any medium, provided the original work is properly cited.

\begin{abstract}
Based on the data of cores, thin sections, well logs, and test experiments, the characteristics and main controlling factors of lamellation fractures in continental shales of the third and fourth members of the Paleogene Qianjiang Formation in the Qianjiang Depression, Jianghan Basin, are studied. Lamellation fractures mainly develop along laminas in shales. They have various morphological characteristics such as straightness, bending, discontinuity, bifurcation, pinching out, and merging. Lamellation fractures with high density show poor horizontal continuity and connectivity characteristics. The average linear density of the lamellation fractures is mainly between $20 \mathrm{~m}^{-1}$ and $110 \mathrm{~m}^{-1}$, and the aperture is usually less than $160 \mu \mathrm{m}$. The density of lamellation fractures is related to their apertures. The smaller the apertures of lamellation fractures are, the higher the density is. The development degree of lamellation fractures is mainly controlled by mineral composition, type, thickness, density of lamination, contents of organic matter and pyrite, lithofacies, structural position, etc. Lamellation fractures develop well, especially under the conditions of medium dolomite content, large lamination density, small lamination thickness, and high total organic carbon (TOC) and pyrite contents. The influences of lithofacies on the lamellation fractures are complex. The lamellation fractures are most developed in carbonaceous layered limestone dolomite and carbonaceous layered dolomite mudstone, followed by stromatolite dolomite filled with carbonaceous pyroxene. The fractures in the massive argillaceous dolomites and carbonaceous massive mudstones are poorly developed. No fractures can be found in the carbonaceous dolomitic, argillaceous glauberites or salt rocks with high glauberite content. Structure is also an important factor controlling lamination fractures. Tectonic uplifts are beneficial to the expansion and extension of lamellation fractures, which increases fracture density. Therefore, when other influence factors are similar, lamellation fractures develop better in the high part of the structure than in the low part.
\end{abstract}

\section{Introduction}

Shale oil refers to the petroleum resource contained in shale $[1,2]$. Oil usually exists in shale pores and natural fractures in the form of adsorption and free states [3, 4]. Natural fractures in shales include structural fractures, lamellation fractures, and fractures related to abnormal high pressure [5, 6]. Among them, lamellation fractures distributed along lamellation provide important reservoir spaces and flow channels, influencing the enrichment, the productivity of a single well, and the development effects of shale oil [7-9].
The research on the distribution rules of lamellation fractures is of great significance for the exploration and development of shale oil.

Some scholars have studied natural fractures in shales [10-12]. Natural fractures in shales can be divided into structural and nonstructural fractures, in which nonstructural fractures are mainly lamellation fractures. The previous works have evaluated and predicted structural fractures in shales by using cores, well logs, seismic data, and finite element numerical simulation methods [13-15]. Lamellation fractures, bedding fractures, bedding parallel fractures, and 
interlayer fractures are natural fractures resulting from the fracturing of shale along or approximately parallel to the direction of lamellations [16-18]. Compared with other rocks, shales have significant layered sedimentary characteristics [19]. These sedimentary interfaces are natural weak interfaces in shale [20]. Under the mechanical compaction, pressure dissolution, acid fluid intrusion, or formation uplift, the fractures are easy to follow along these interfaces [21-23]. Besides, the local abnormal high pressure formed in the process of mature hydrocarbon expulsion of organic matter causes the vertical maximum principal stress of the formation to change from compression to tension $[24,25]$. When the pressure breaks through the shale fracture strength, the lamellation fractures can be formed [26]. Due to the small scale of lamellation fractures, the controlling factors of lamellation fractures are still unclear and the prediction of the distribution rule of lamellation fractures is very difficult. Therefore, the studies of the development characteristics and control factors of lamellation fractures are important.

By taking the third and fourth members of the Paleogene Qianjiang Formation in the Qianjiang Depression, Jianghan Basin as the target, based on cores, thin sections, image logging, and testing experiment data, the characteristics and main control factors of lamellation fractures are analyzed, and the formation mechanism of lamellation fractures is discussed in the paper. This study can potentially provide guidelines for understanding the development rule of lamellation fractures in continental shale oil reservoirs.

\section{Geological Setting}

2.1. Structure. The Jianghan Basin, located in the middle of the Yangtze Plate, is a faulted basin formed under the background of tectonic extensions from Cretaceous to Paleogene [27]. The Qianjiang Depression is in the middle of the Jianghan Basin, with an area of $2530 \mathrm{~km}^{2}$, which is the main depression generating hydrocarbon in the Jianghan Basin $[28,29]$. The northwest of the Qianjiang Depression is bounded by the Qianbei fault, and the other three directions of the Qianjiang Depression are uplift (Figure 1). The NESW normal faults are commonly developed in the Qianjiang Depression. In addition, a few small-scaled normal faults of E-W, N-S, and NW-SE directions exist.

2.2. Stratigraphy. The Cretaceous, Paleogene, Neogene, and Quaternary strata exist in the Jianghan Basin (Figure 2). The Paleogene is a typical continental salt lake basin. The corresponding climate, lake level, and water salinity change rapidly and periodically, making a very thick salt layer deposited in the basin [30-33]. The Paleogene Qianjiang Formation is the main salt-bearing strata, which can be divided into four members and then further subdivided into 193 rhythmic salt layers whose thicknesses are from several meters to tens of meters [34].

The third and fourth members of the Qianjiang Formation are the main reservoirs of shale oil exploration due to the rich organic matters and high oil content. Hence, the two members are selected as the key strata in this paper. In the third and fourth members, salt rocks and shales are well interbedded. Based on organic geochemical analyses, the intersalt shale has a good capacity to generate hydrocarbons, and the total oil production is more than $40 \times 10^{8} \mathrm{t}$ [35].

The thickness of the fourth member is large, ranging from $178 \mathrm{~m}$ to $2218 \mathrm{~m}$. The lithology of the fourth member of the Qianjiang Formation consists of dark grey oil shale, glauberite-filled dolomitic mudstone, salt rock, etc. In the lower part of the structure, the lithology is mainly shale. In the upper part, in addition to a large amount of shale, there are some siltstone and fine-grained sandstone.

The thickness of the third member of the Qianjiang Formation is between $150 \mathrm{~m}$ and $640 \mathrm{~m}$. This member can be divided into 14 rhythmic layers. The main lithology is dark gray and brown gray intersalt shales. Siltstones and argillaceous limestones appear in the upper section of this member.

Due to the barrier of salt layer, it is difficult for oil and gas to migrate vertically but can migrate horizontally. After the migration, the remaining oil and gas are retained in shales, which results into a multilayered intersalt shale reservoir. This kind of reservoir is quite important for the oil and gas exploration in the Qianjiang Depression [36-39].

2.3. Reservoir. The Paleogene Qianjiang Formation is the main source rock of the Jianghan Basin. Based on the core analysis of 256 samples, the lithology of intersalt reservoir mainly includes mudstones, shales, argillaceous dolomites, dolomitic mudstones, and glauberite-filled dolomitic mudstones. The X-ray diffraction (XRD) analysis of 315 samples indicates that minerals mainly include clastic minerals, carbonate minerals, and salt [35]. For clay mineral, illite is the main component with a content range from $60 \%$ to $82 \%$ and the average value of $72 \%$. The illite/smectite mixed layer is the second major component in the clay minerals with a content range from $10 \%$ to $40 \%$ (average $27 \%$ ). No kaolinite can be found in clay mineral. The ratio of clay minerals generally corresponds to the arid paleoclimate and the salt lake water rich in $\mathrm{K}^{+}$. For carbonate mineral, dolomite is the main component with an average content of $35 \%$. The content of dolomite varies greatly in different depths due to the changes of sedimentary microfacies. For salt rock, glauberite is the main component with an average content of $25 \%$ [35]. Besides, the lithology also contains a small amount of quartz, feldspar, pyrite, and other clastic rock minerals and authigenic minerals.

The scanning electron microscope (SEM) analysis of 315 thin sections indicates that the reservoir space includes dolomite intergranular pore, glauberite intergranular pore, dolomite dissolution pore, glauberite dissolution pore, and fracture. Among them, the ratio of porous reservoir is about $36 \%$, and that of fractured reservoir is $64 \%$. This means that natural fractures provide the main reservoir space in shale reservoirs of the Qianjiang Formation. The core analysis of 256 samples shows that the range of porosity is between $8 \%$ and $18 \%$ in the third and fourth members of the Qianjiang Formation with the average value of $14.3 \%$. Typically, porosity is directly positively proportional to dolomite content and 


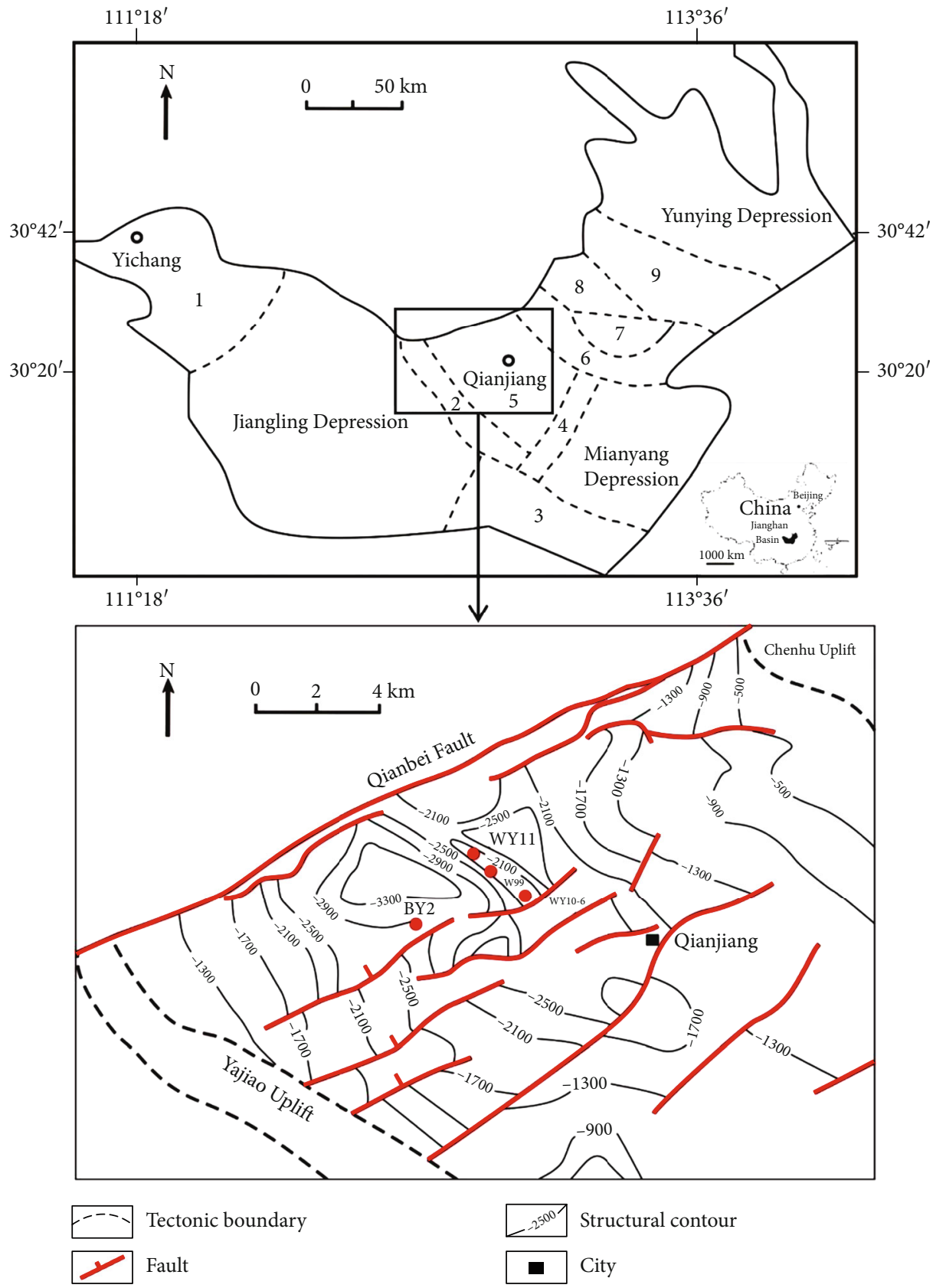

Figure 1: The structure of the Qianjiang Depression in the Jianghan Basin. 1: Zhijiang Depression; 2: Yajiao Uplift; 3: Chentuokou Depression; 4: Tonghaikou Uplift; 5: Qianjiang Depression; 6: Chenhu Uplift; 7: Xiaoban Depression; 8: Tianmen Uplift; 9: Longsaihu Uplift.

inversely proportional to glauberite content. In the target formation, the permeability of the shale reservoir permeability ranges between $0.08 \mathrm{mD}$ and $925 \mathrm{mD}$ with the average value of $43.4 \mathrm{mD}$. The permeability varies widely due to natural fractures in reservoirs [4].

\section{Characteristics of Lamellation Fractures}

Lamellation fractures refer to the natural fracture formed during sedimentation and diagenesis, which are distributed along the lamellation planes [9]. Based on observations of $1300 \mathrm{~m}$ cores and 725 thin sections from 8 wells, the lamellation fractures are mainly developed along the shale laminae and are nearly parallel to the arrangement direction of plastic minerals with the inclinations of the lamellation less than $10^{\circ}$. Lamellation fractures have various morphological characteristics such as straightness, bending, discontinuity, bifurcation, pinching out, and merging (Figure 3). The horizontal continuity and connectivity of lamellation fractures are usually poor. The margins of the most lamellation fractures are indistinct and have obvious dissolution. According to the core statistics, the linear density of the lamellation fractures mainly ranges between $30 \mathrm{~m}^{-1}$ and $110 \mathrm{~m}^{-1}$ (Figure 4) and about $27.2 \%$ of lamellation fractures are filled mainly by glauberite. The observation results of thin sections show the apertures of the lamellation fractures are generally less than 


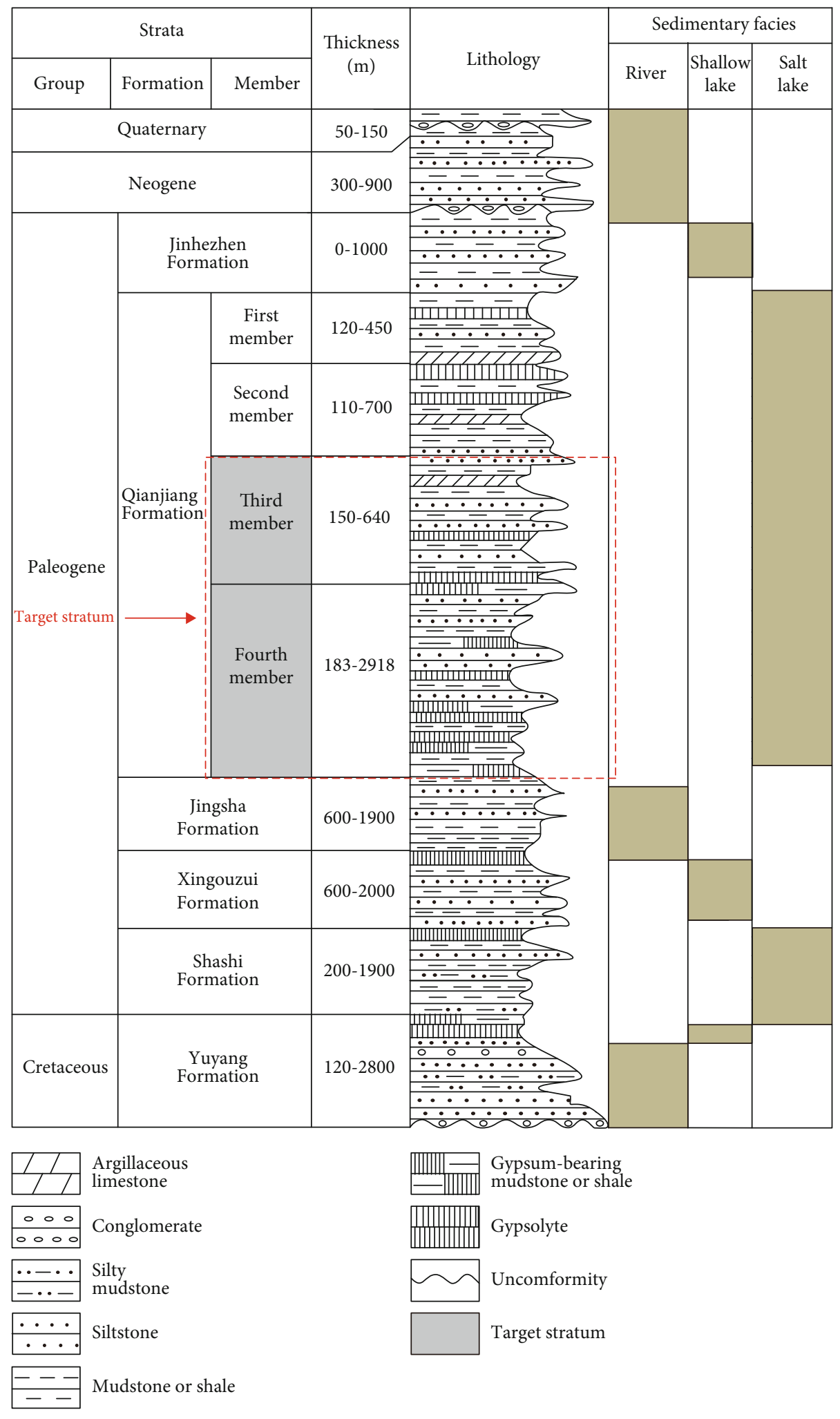

Figure 2: Stratigraphic column in the Qianjiang Depression (modified from Bai et al., 2014).

$160 \mu \mathrm{m}$. The density of lamellation fractures shows a negative exponential function relation with the aperture. The larger the density of lamellation fractures have, the smaller the aperture is (Figure 5).

\section{Influencing Factors of Lamellation Fractures}

According to the analysis of cores, thin sections, and imaging $\log$ data, the development degree of lamellation fractures is 


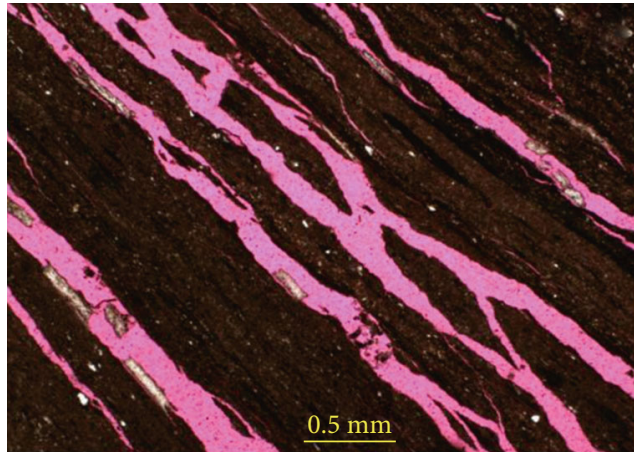

(a)

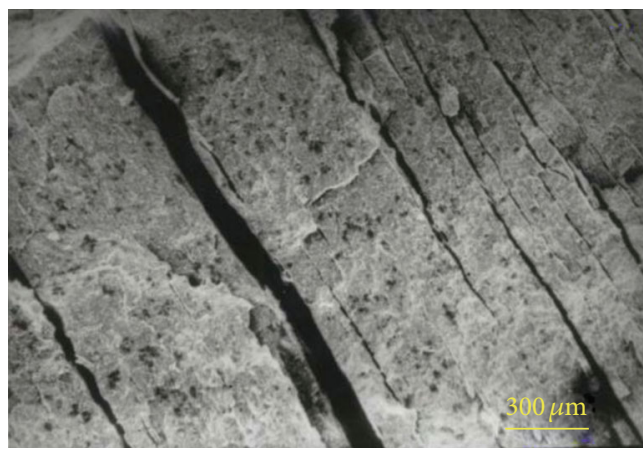

(c)

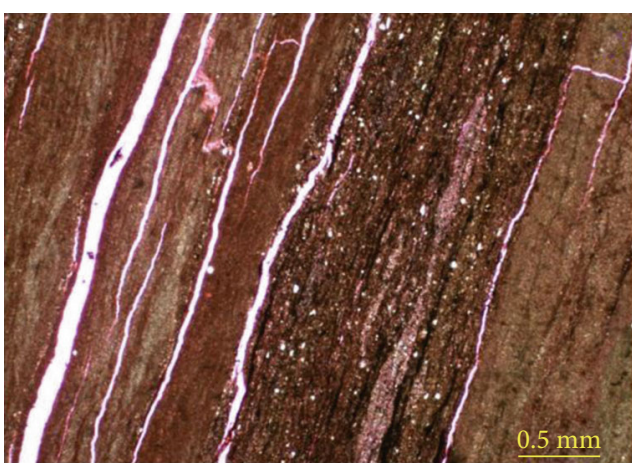

(b)

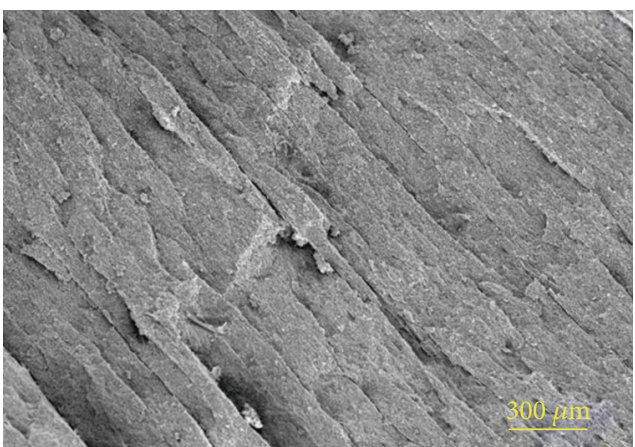

(d)

Figure 3: Distribution characteristics of lamellation fractures in the Paleogene shales in the Qianjiang Depression. (a) Casting thin section at depth of $1629.6 \mathrm{~m}$ from WY11 well. (b) Casting thin section at depth of $1559.3 \mathrm{~m}$ from WY11. (c) Scanning electron microscope at depth of 1491.2 m from WY10-6 well. (d) Scanning electron microscope at depth of $1746.7 \mathrm{~m}$ from WY11 well.

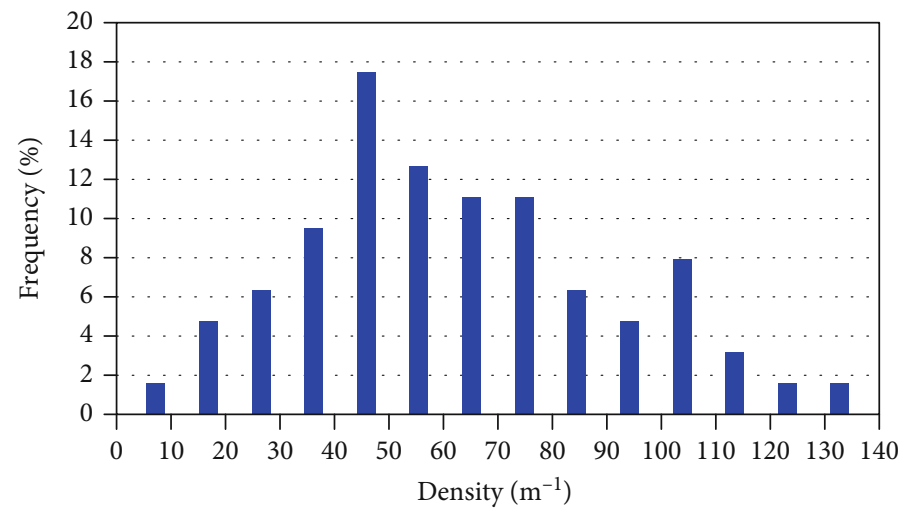

Figure 4: Density distribution of lamellation fractures in the Qianjiang Depression $(N=828)$.

related to organic content, mineral components, texture and structure of lamina and structural position, etc.

4.1. Organic Content. The development of lamellation fractures is closely related to organic matter [40]. The organic matter of the target layer has undergone sufficient evolution and is basically in the mature stage [41]. The vitrinite reflectance (Ro) of the third member of the Qianjiang Formation shales ranges from $0.50 \%$ to $0.88 \%$, and the Ro of the fourth member is between $0.55 \%$ and $1.30 \%$. The density of lamellation fractures in marine shales is closely related to the content of organic carbon $[9,14]$. Similarly, the density of lamellation fractures in continental shales is also positively correlated with the TOC content. The higher the TOC content is, the higher the density of lamellation fractures is (Figure 6).

In the process of organic matter maturation and hydrocarbon expulsion, the formation of a large number of hydrocarbons will increase the pore fluid pressure which leads to local abnormal high pressures [41-44]. These local abnormal high pressures can make the weak mechanical discontinuities preferentially crack to form lamellation fractures. The higher the TOC content in shales is, the more fluid is produced in 


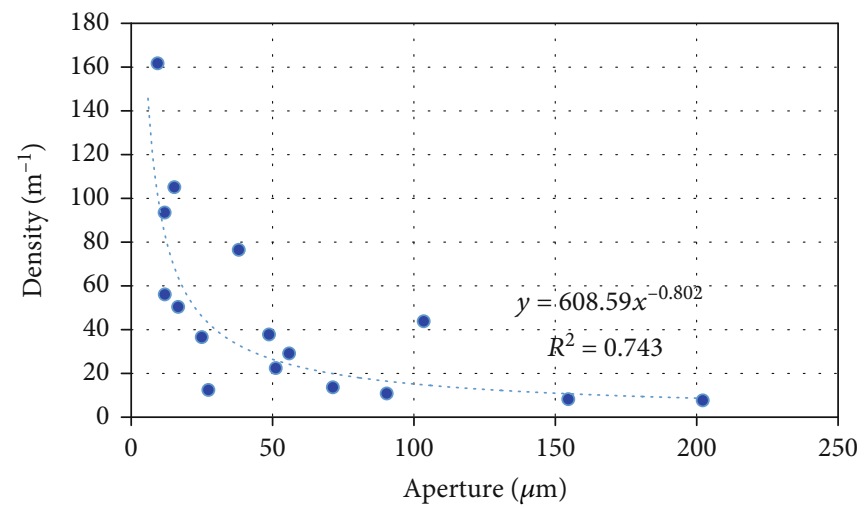

Figure 5: Relationship between density and aperture of lamellation fractures in the Qianjiang Depression.

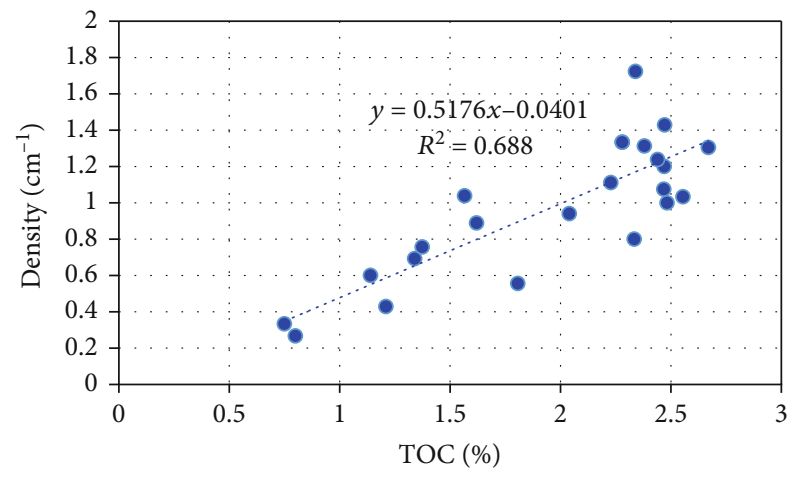

Figure 6: Relationship between density of lamellation fractures and TOC content in the Qianjiang Depression.

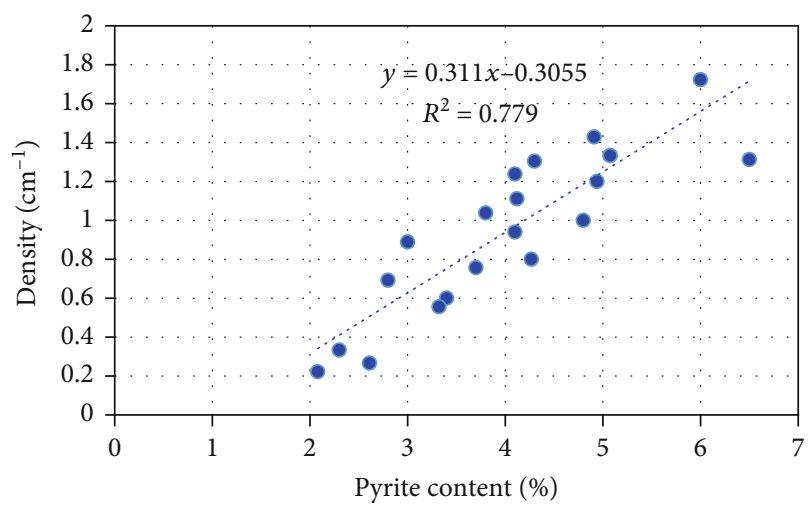

Figure 7: Relationship between density of lamellation fractures and pyrite content in the Qianjiang Depression.

the hydrocarbon generation process, and subsequently, the higher the development degree of foliation fractures is. Therefore, the lamellation fractures often appear in areas with rich organic matters. The formation environment of lake facies rich in organic matters is similar to that of pyrite [45]. High organic matters could indicate high pyrite in the Qianjiang Formation [46]. From this study, Figure 7 shows that the density of the lamellation fractures increases with the increasing pyrite content, indicating that for the target area, pyrite can also be the indicator for the evaluation of the lamellation fractures.

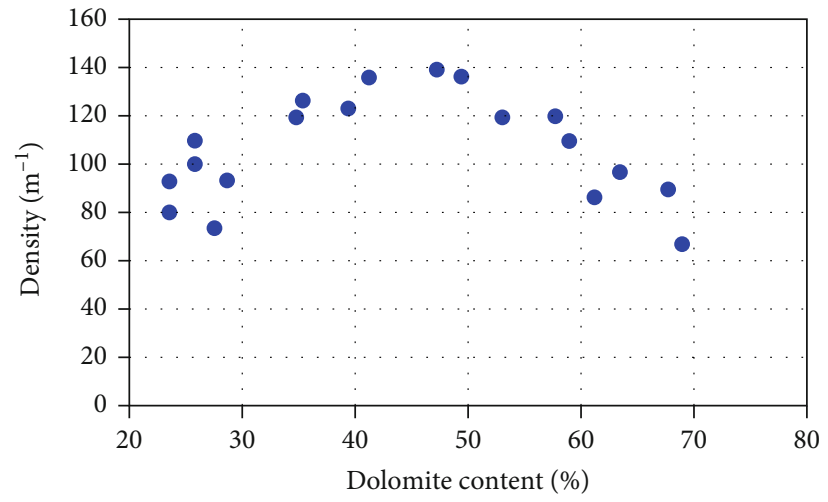

FIgURE 8: Relationship between density of lamellation fractures and dolomite content in the Qianjiang Depression.

4.2. Mineral Components. The density of lamellation fractures is closely related to the mineral components in shales. Shales mainly consist of clastic minerals, salt rock minerals, and carbonate minerals. Among them, dolomite is the most important brittle mineral in shales. According to the statistics results from thin sections, the density of the lamellation fractures is related to the content of brittle minerals (e.g., dolomite). For example, the fracture density is the largest when dolomite content is about $50 \%$ in the study area. When focusing on the range of dolomite content between 0 and $50 \%$, it is shown that the higher the dolomite content is, the more lamellation fractures develop. Due to the increase in dolomite content, the brittleness of shale is improved, and shale is more likely to fracture. When the content of the dolomite is greater than $50 \%$, the degree of development of the lamellation fractures will decline accordingly. Higher dolomite content means a drier sedimentary environment, which is not conducive to the enrichment of organic matter. Even if the organic-poor shale formed in this sedimentary environment has high brittleness, it is not conducive to the formation of lamellation fractures (Figure 8). In the formations with a large amount of salt rocks (especially glauberite), the development of the lamellation fractures will be significantly reduced.

4.3. Texture and Structure of Lamina. The distribution of the lamellation fractures is related to the type, thickness, and 


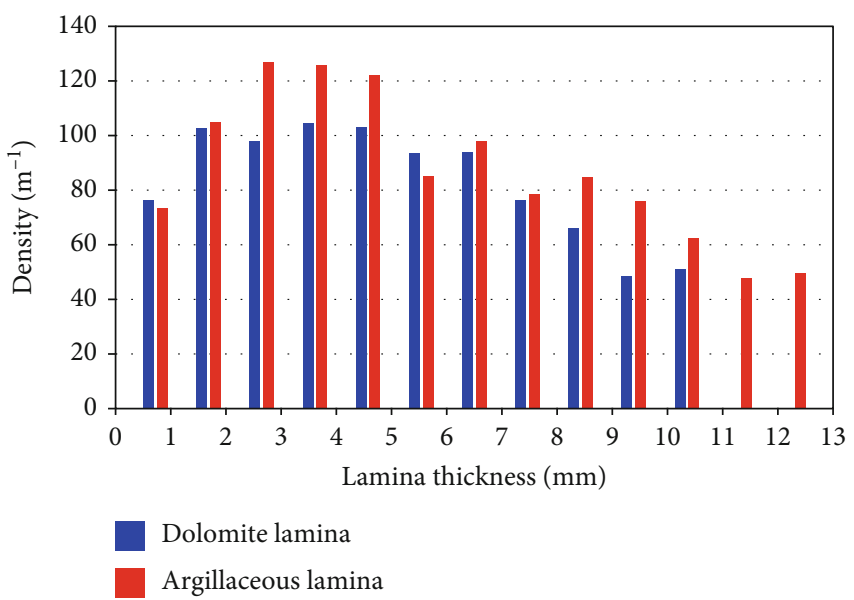

Figure 9: Relationship between density of lamellation fractures and thickness of lamina in the Qianjiang Depression $(N=283)$.

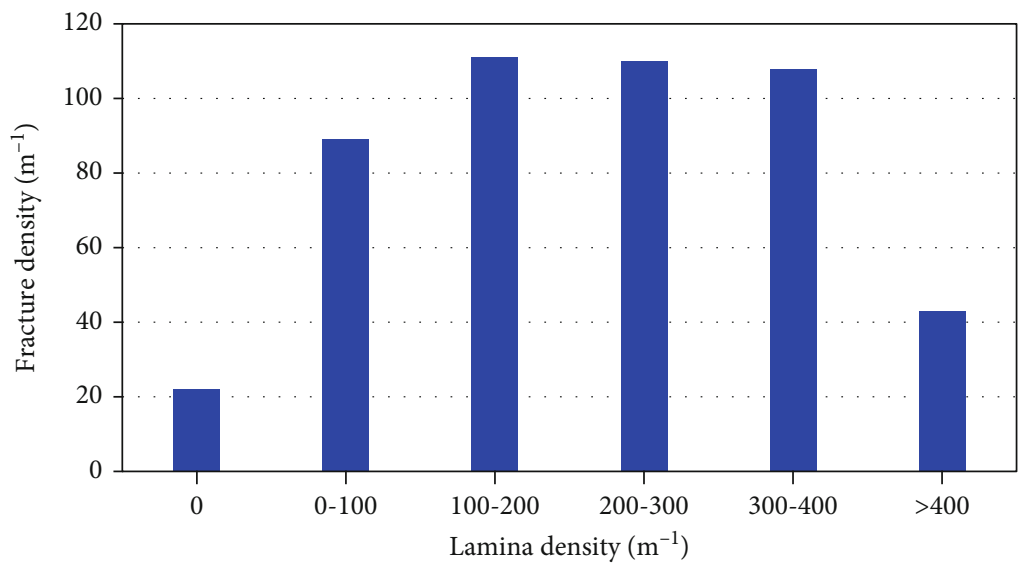

FIgURE 10: Relationship between density of lamellation fractures and lamina in the Qianjiang Depression $(N=828)$.

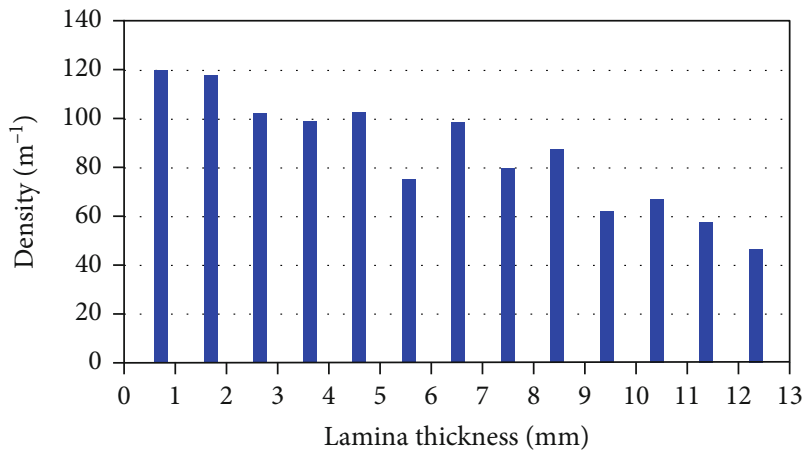

FIGURE 11: Relationship between density of lamellation fractures and thickness of glauberite lamina in the Qianjiang Depression $(N=182)$.

density of lamina. The third and fourth members of the Qianjiang Formation are rich in laminas which are consisted of argillaceous, dolomitic, and glauberite lamination. Based on observations of lamellation fractures and laminas in rock cores, the lamellation fractures mainly develop around the lithologic change interfaces with frequent interbedding of dolomitic and muddy laminations. On the contrary, due to the lack of these weak mechanical discontinuities in massive rocks, lamellation fractures usually do not develop well in massive rocks.

The statistical results of core observations also indicate that the development degree of lamellation fractures is related to the thickness of dolomitic and muddy laminations (Figure 9). As the thickness of lamina is distributed between $1 \mathrm{~mm}$ and $4 \mathrm{~mm}$, the density of lamellation fractures is relatively high and the average density is more than $100 \mathrm{~m}^{-1}$. As the thickness of the lamina is more than $4 \mathrm{~mm}$, the density of the lamellation fractures is inversely proportional to lamina thickness. As lamina thickness is less than $1 \mathrm{~mm}$, this relation will become proportional. Meanwhile, the density of the lamellation fractures is also related to the density of the dolomitic and muddy lamina (Figure 10). As the density of lamina is between $100 \mathrm{~m}^{-1}$ and $400 \mathrm{~m}^{-1}$, the density of lamellation fractures is the relatively high. As the lamina density is more than $400 \mathrm{~m}^{-1}$ or less than $100 \mathrm{~m}^{-1}$, the density of the lamellation fractures decreases.

Unlike from dolomite and argillaceous laminations, glauberite laminations often fall into unconsolidated argillaceous deposits in the form of self-shaped snowflakes where 


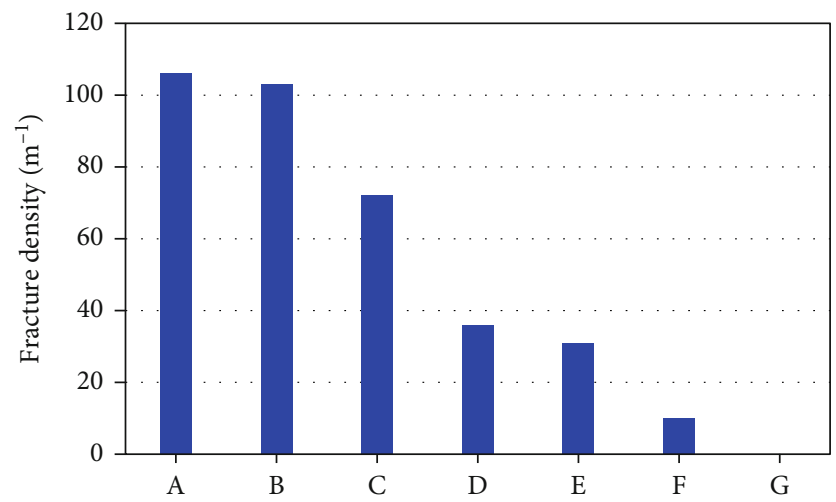

Figure 12: Density of lamellation fractures in different lithofacies in the Qianjiang Depression $(N=829)$. A: carbonaceous bedded argillaceous dolomite; B: carbonaceous laminated dolomite or calcareous mudstone; C: carbonaceous glauberite-filled laminated argillaceous dolomite; D: carbonaceous massive argillaceous dolomite; E: carbonaceous massive mudstone; F: carbonaceous dolomite or argillaceous glauberite; G: salt.

continuous weak mechanical discontinuities often do not appear. Therefore, in the shales with glauberite laminations, the density of lamellation fractures has negative correlations with both the thickness and the density of the glauberite laminations (Figure 11). As the density and thickness of glauberite lamination increase, the density of lamellation fractures decreases.

4.4. Lithofacies. Based on the mineral composition, bedding structure, and organic matter content, the salt rock can be divided into seven main lithofacies, i.e., argillaceous dolomite rich in laminated carbonaceous lamina, dolomitic or limy mudstone rich in laminated carbonaceous lamina, argillaceous dolomite rich in carbonaceous glauberite lamina, massive carbonaceous argillaceous dolomite, massive carbonaceous mudstone, carbonaceous dolomitic or argillaceous glauberite, and salt rock. Here, rocks with a TOC content of more than $2 \%$ are defined as carbon-rich rocks, those with a TOC content between $0.5 \%$ and $2 \%$ are carboncontaining rocks, and those with a TOC content of less than $0.5 \%$ are carbon-poor rocks [46]. Therefore, the comprehensive influences of mineral composition, bedding texture, structure, and organic matter content on the density of lamellation fractures can be summarized as the control of lithofacies on the development of lamellation fractures.

According to the statistics of lamellation fractures observed in cores (Figure 12), the density of lamellation fractures in the argillaceous dolomites rich in laminated carbonaceous lamina and dolomitic or limy mudstones rich in laminated carbonaceous lamina is the largest with the average density of more than $100 \mathrm{~m}^{-1}$. In the argillaceous dolomite-rich carbonaceous glauberite lamina, the average density is more than $70 \mathrm{~m}^{-1}$. The density of lamellation fractures in the carbonaceous massive argillaceous dolomites and carbonaceous massive mudstones is less than $40 \mathrm{~m}^{-1}$. These differences indicate that densities of lamellation fractures in massive carbonaceous lithofacies are far lower than those in lithofacies rich in laminated carbonaceous lamina. The lamellation fractures are not developed in salt rocks, carbonaceous dolomitic or argillaceous glauberites.
4.5. Structural Position. The development degree of the lamellation fractures is also affected by structures. Different structural positions correspond to different density of the lamellation fractures. For example, W99 well at the high position of an anticline axis and BY2 well at the low position of depression are used for the comparison (Figure 1). The two wells have similar TOC content and lamina in shales. The TOC contents in the fourth section of the third member in the Qianjiang Formation in two wells are both in the range from $3.0 \%$ to $4.0 \%$. The laminas are dolomitic lamina and muddy lamina with thickness between $1 \mathrm{~mm}$ and $4 \mathrm{~mm}$ in shales. However, the lamellation fracture densities of the two wells in the same layer are different. The average density of W99 and BY2 wells are $111 \mathrm{~m}^{-1}$ and $54 \mathrm{~m}^{-1}$, respectively. The lamellation fracture density in the W99 well at the high structural position is higher than that in the BY2 well at the low structural position. The density difference of lamellation fracture results from their structural positions. Under the structural compression, the high position (W99) in the axis of anticline uplifted and eroded which leads to the overlying formation pressure reduced. The reduced overlying pressure will promote lamellation fractures, further expanding along the weak mechanical discontinuities and subsequently leading to high density of lamellation fractures, indicating that the development degree of the lamellation fractures at the high structural position is better than that at the low structural position.

\section{Conclusion}

Lamellation fractures mainly develop along lamellations in shales. They have various morphological characteristics such as straightness, bending, discontinuity, bifurcation, pinching out, and merging. The horizontal continuity and connectivity of the lamellation fractures are poor. The lamellation fractures are well developed in the Paleogene Qianjiang Formation shales, and the density of the lamellation fractures mainly lies between $20 \mathrm{~m}^{-1}$ and $110 \mathrm{~m}^{-1}$. The aperture of lamellation fracture is generally less than $160 \mu \mathrm{m}$. The density of lamellation fracture is related to its aperture; the 
smaller the lamellation fracture apertures is, the higher the density is.

The development degree of the lamellation fractures is mainly controlled by mineral composition, texture type, quantity and density of lamina, organic matter content, pyrite content, and structural position. The densities of lamellation fractures in argillaceous dolomites rich in laminated carbonaceous lamina and dolomitic or limy mudstones rich in laminated carbonaceous lamina are the largest, followed by the density of the factures in argillaceous dolomite-rich carbonaceous glauberite lamina. In massive carbonaceous argillaceous dolomites and massive carbonaceous mudstones, the densities of lamellation fractures are low. The lamellation fractures are not developed in carbonaceous dolomitic or argillaceous glauberites and salt rocks. The uplift of tectonic movement is conducive to the development degree of lamellation fractures. In the same lithofacies, the lamellation fractures in the high structural position are more developed than those in the low structural position.

\section{Data Availability}

The [data type] data used to support the findings of this study are available from the corresponding author upon request.

\section{Conflicts of Interest}

The authors declare that they have no conflicts of interest.

\section{Acknowledgments}

This study was financially supported by the National Natural Science Fund Projects (Grant No. U1663203) and National Science and Technology Major Project (Grant No. 2017ZX05049).

\section{References}

[1] S. LU, W. HUANG, F. CHEN et al., "Classification and evaluation criteria of shale oil and gas resources: discussion and application," Petroleum Exploration and Development, vol. 39, no. 2, pp. 268-276, 2012.

[2] J. Zhang, L. Lin, and Y. Li, "Classification and evaluation of shale oil," Earth Science Fronitiers, vol. 19, no. 5, pp. 322331, 2012.

[3] C. Zou, Z. Yang, J. Cui et al., "Formation mechanism, geological characteristics and development strategy of nonmarine shale oil in China," Petroleum Exploration and Development, vol. 40, no. 1, pp. 15-27, 2013.

[4] Z. Jiang, W. Zhang, C. Liang, Y. Wang, H. Liu, and X. Chen, "Characteristics and evaluation elements of shale oil reservoir," Shiyou Xuebao/Acta Petrolei Sinica, vol. 35, no. 1, pp. 184-196, 2014.

[5] H. Wang, Z. He, Y. Zhang, K. Su, R. Wang, and C. Zhao, "Microfracture types of marine shale reservoir of Sichuan Basin and its influence on reservoir property," Oil and Gas Geology, vol. 40, no. 1, pp. 41-49, 2019.

[6] Z. He, H. Nie, J. Zhao, W. Liu, F. Bao, and W. Zhang, "Types and origin of nanoscale pores and fractures in Wufeng and Longmaxi shale in Sichuan Basin and its periphery," Journal of Nanoscience and Nanotechnology, vol. 17, no. 9, pp. 66266633, 2017.

[7] J. F. W. Gale, R. M. Reed, and J. Holder, "Natural fractures in the Barnett shale and their importance for hydraulic fracture treatments," American Association of Petroleum Geologists Bulletin, vol. 91, no. 4, pp. 603-622, 2007.

[8] J. F. W. Gale and J. Holder, "Natural fractures in some US shales and their importance for gas production," Petroleum Geology Conference Proceedings, vol. 7, no. 1, pp. 1131-1140, 2010.

[9] L. Zeng, W. Lyu, J. Li et al., "Natural fractures and their influence on shale gas enrichment in Sichuan Basin, China," Journal of Natural Gas Science and Engineering, vol. 30, pp. 1-9, 2016.

[10] L. Zeng and S. Xiao, "Fractures in mudstone of tight reservoirs (in Chinese with English abstract): experimental petroleum geology," Experimental Petroleum Geology, vol. 21, no. 3, pp. 266-269, 1999.

[11] W. Ding, C. Li, C. Li et al., "Fracture development in shale and its relationship to gas accumulation," Geoscience Frontiers, vol. 3, no. 1, pp. 97-105, 2012.

[12] J. F. W. Gale, S. E. Laubach, J. E. Olson, P. Eichhubl, and A. Fall, "Natural fractures in shale: a review and new observations," AAPG Bulletin, vol. 101, no. 8, pp. 2165-2216, 2014.

[13] M. Kobchenko, H. Panahi, F. Renard et al., "4D imaging of fracturing in organic-rich shales during heating," Journal of Geophysical Research: Solid Earth, vol. 116, no. B12, article B12201, 2011.

[14] W. Ding, D. Zhu, J. Cai, M. Gong, and F. Chen, "Analysis of the developmental characteristics and major regulating factors of fractures in marine-continental transitional shale-gas reservoirs: a case study of the carboniferous-Permian strata in the southeastern Ordos Basin, central China," Marine and Petroleum Geology, vol. 45, pp. 121-133, 2013.

[15] W. Zeng, J. Zhang, W. Ding et al., "Fracture development in Paleozoic shale of Chongqing area (south China). Part one: fracture characteristics and comparative analysis of main controlling factors," Journal of Asian Earth Sciences, vol. 75, pp. 251-266, 2013.

[16] Y. Zhang, Z. He, S. Jiang et al., "Fracture types in the lower Cambrian shale and their effect on shale gas accumulation, upper Yangtze," Marine and Petroleum Geology, vol. 99, pp. 282-291, 2019.

[17] Y. Gu, W. Ding, Q. Tian et al., "Developmental characteristics and dominant factors of natural fractures in lower Silurian marine organic-rich shale reservoirs: a case study of the Longmaxi formation in the Fenggang block, southern China," Journal of Petroleum Science and Engineering, vol. 192, article 107277, 2020.

[18] R. Wang, W. Ding, Y. Zhang et al., “Analysis of developmental characteristics and dominant factors of fractures in Lower Cambrian marine shale reservoirs: a case study of Niutitang formation in Cen'gong block, southern China," Journal of Petroleum Science and Engineering, vol. 138, pp. 31-49, 2016.

[19] X. Zhang, W. Shi, Q. Hu et al., "Developmental characteristics and controlling factors of natural fractures in the lower paleozoic marine shales of the upper Yangtze Platform, southern China," Journal of Natural Gas Science and Engineering, vol. 76, article 103191, 2020.

[20] X. Wang, R. Wang, W. Ding et al., "Development characteristics and dominant factors of fractures and their significance for 
shale reservoirs: a case study from $€ 1 \mathrm{~b} 2$ in the Cen'gong block, southern China," Journal of Petroleum Science and Engineering, vol. 159, pp. 988-999, 2017.

[21] K. Jiu, W. L. Ding, W. H. Huang, Y. Zhang, S. Zhao, and L. Hu, "Fractures of lacustrine shale reservoirs, the Zhanhua depression in the Bohai Bay basin, eastern China," Marine and Petroleum Geology, vol. 48, pp. 113-123, 2013.

[22] D. N. Dewhurst, A. F. Siggins, J. Sarout, M. D. Raven, and H. M. Nordgard-Bolas, "Geomechanical and ultrasonic characterization of a Norwegian Sea shale," Geophysics, vol. 76, no. 3, pp. WA101-WA111, 2011.

[23] A. M. Allan, T. Vanorio, and J. E. P. Dahl, "Pyrolysis-induced P-wave velocity anisotropy in organic-rich shales," Geophysics, vol. 79, no. 2, pp. D41-D53, 2014.

[24] G. G. Lash and T. Engelder, "An analysis of horizontal microcracking during catagenesis: example from the Catskill delta complex," American Association of Petroleum Geologists Bulletin, vol. 89, no. 11, pp. 1433-1449, 2005.

[25] P. R. Cobbold, A. Zanella, N. Rodrigues, and H. Løseth, "Bedding-parallel fibrous veins (beef and cone-in-cone): worldwide occurrence and possible significance in terms of fluid overpressure, hydrocarbon generation and mineralization," Marine and Petroleum Geology, vol. 43, pp. 1-20, 2013.

[26] Y. Luo, H. Liu, Y. Zhao, and G. Wang, "Effects of gas generation on stress states during burial and implications for natural fracture development," Journal of Natural Gas Science and Engineering, vol. 30, pp. 295-304, 2016.

[27] L. Wu, L. Mei, Y. Liu et al., "The stratigraphic and structural record of the Cretaceous Jianghan Basin, central China: implications for initial rifting processes and geodynamics," Cretaceous Research, vol. 90, pp. 21-39, 2018.

[28] S. Dai, Petroleum Geology in the Jianghan Salt Lake Basin, Petroleum Industry Press, Beijing, 1997.

[29] S. Wu, X. Tang, X. Du, W. Liang, and Q. He, "Geologic characteristics of continental shale oil in the Qianjiang depression, Jianghan salt lake basin," Journal of east china institute of technology, vol. 36, no. 3, pp. 282-286, 2013.

[30] Y. Zhang, Y. Yang, and Z. Qi, "Sedimentary characteristics and environments of the salt-bearing series of Qianjiang formation of the Paleogene in Qianjiang sag of Jianghan basin," Journal of Palaeogeography, vol. 6, no. 1, pp. 29-35, 2003.

[31] B. J. Liu, K. Y. Chen, Z. S. Shi, G. Liu, and J. B. Lu, "Reservoir prediction of the saline deposit in the Qianjiang sag, Jianghan Basin," Shiyou Kantan Yu Kaifa/Petroleum Exploration and Development, vol. 31, no. 2, p. 74, 2004.

[32] G. Wang, Y. Yang, Y. Zhang, Z. Qi, Y. Qiao, and S. Yuan, “Sedimentary microfacies and evolution of the Qianjiang formation of Paleogene at Wangchang area in Qianjiang sag, Jianghan Basin," Journal of Palaeogeography, vol. 7, no. 2, pp. 140-150, 2004.

[33] B. Jianxin, W. Shi, and Y. He, "Controlling factors and sequence models of the lower 4th member of Qianjiang formation in northern area of Qianjiang sag," China Petroleum Exploration, vol. 19, no. 1, pp. 22-30, 2014.

[34] Z. Fang, Sedimentary Filling Model in the Jianghan Salt Lake Basin, Petroleum Industry Press, Beijing, 2006.

[35] F. Wang, S. He, Y. Zheng, Y. Hou, and S. Wu, "Mineral composition and brittleness characteristics of the inter- salt shale oil reservoirs in the Qianjiang formation Qianjiang sag," Petroleum Geology \& Experiment, vol. 38, no. 2, pp. 211-218, 2016.
[36] F. L. Chen, "Structural evolution and deposinal packing as well as hydrocarbon accumulation in Qianjiang salt lake basin," Journal of Oil and Gas Technology, vol. 29, no. 2, pp. 50-53, 2007.

[37] Y. Zheng, "Exploration direction and strategy for lithologic accumulations in Qianjiang formation of the Qianjiang sag, Jianghan basin," petroleum Geology \& Experiment, vol. 32, no. 4, pp. 330-333, 2010.

[38] K. Wang, J. Ye, F. Guo, X. Li, and J. Chen, "Characteristics and hydrocarbon generation- expulsion history of source rock of Banghu syncline in Qianjiang depression," Geological Science and Technology Information, vol. 30, no. 5, pp. 83-88, 2011.

[39] Y. Hou, F. Wang, S. He, T. Dong, and S. Wu, "Properties and shale oil potential of saline lacustrine shales in the Qianjiang depression, Jianghan Basin, China," Marine and Petroleum Geology, vol. 86, pp. 1173-1190, 2017.

[40] L. Gong, J. Wang, S. Gao et al., "Characterization, controlling factors and evolution of fracture effectiveness in shale oil reservoirs," Journal of Petroleum Science and Engineering, vol. 203, article 108655, 2021.

[41] C. Barker, "Calculated volume and pressure changes during the thermal cracking of oil to gas in reservoirs," American Association of Petroleum Geologists Bulletin, vol. 74, no. 8, pp. 1254-1261, 1990.

[42] S. Li, Y. Yuan, W. Sun, D. Sun, and Z. Jin, "Formation and destruction mechanism as well as major controlling factors of the Silurian shale gas overpressure in the Sichuan Basin, China," Journal of Natural Gas Geoscience, vol. 1, no. 4, pp. 287-294, 2016.

[43] J. Gao, J. K. Zhang, S. He et al., "Overpressure generation and evolution in Lower Paleozoic gas shales of the Jiaoshiba region, China: implications for shale gas accumulation," Marine and Petroleum Geology, vol. 102, pp. 844-859, 2019.

[44] X. Wang, Z. Jiang, S. Jiang et al., "Pore evolution and formation mechanism of organic-rich shales in the whole process of hydrocarbon generation: study of artificial and natural shale samples," Energy and Fuels, vol. 34, no. 1, pp. 332-347, 2020.

[45] L. I. U. BBo, L. Ü. Yanfang, M. E. N. G. Yuanlin et al., "Petrologic characteristics and genetic model of lacustrine lamellar fine-grained rock and its significance for shale oil exploration: a case study of Permian Lucaogou formation in Malang sag, Santanghu Basin, NW China," Shiyou Kantan Yu Kaifa/Petroleum Exploration and Development, vol. 42, no. 5, pp. 598-607, 2015.

[46] Z. Sun, F. Wang, Y. Hou et al., "Spatial characterization and influenceing factors of soluble organic matter in shale of Qiangjiang formation in Qianjiang depression," Geological Science and Technology Information, vol. 38, no. 6, pp. 81-90, 2019. 